\title{
Innovation-oriented Land-use Policy at the Sub-national Level : Case Study from Germany ${ }^{\dagger}$
}

\author{
Peter FRIEDRICH* and Chang Woon NAM**
}

\begin{abstract}
This study introduces a two-stage competition model to investigate major features of land-use strategies for German municipalities. First, a municipality should solve economic and interest conflicts related to its preference of high-quality sites for high-tech firms against other land needs. Second, competition among municipalities with high-quality sites is necessary for attracting innovative firms. A local land-use policy is combined with the industrial policy in Germany : for Potsdam the study reveals strengths and weaknesses of the real estate market in the context of urban competition for attracting high-tech firms, and examines its future chances and risks for the location of various economic activities with particular consideration of local clusters. Science Park Adlershof (Berlin) appears to provide a successful combination of technology policies and municipal land-zoning strategies to guarantee a superior position in the competition for creating incubators for innovative small and medium-sized enterprises. Municipalities also cooperate, because such cooperation provides larger sites, generates economies of scale and contributes to a smooth suburbanization process.
\end{abstract}

JEL Classification : H42, O3, R52, R58

Keywords : Innovation, Land-use Policy, Zoning, Municipal Competition, Technology Park, Germany

\section{Introduction}

In several European countries, including Germany, land-use policy is carried out at the sub-national level (Newman and Thornley, 1996 ; Kersten, 2011), for which justification is based on what is termed the subsidiarity principle. Local or regional economies are currently directed both inwards (to develop their own innovative capacities) and outwards (to compete in global markets) (see also Florida, 2004 ; McCann, 2007 ; Cohendet $e t$ al., 2010). It is a generally acknowledged fact that the basic innovation ${ }^{1}$ carried out by firms creates new industries, drives the business cycle and provides the basis for long-term economic growth (Schumpeter, 1934 ; Grossman and Helpman, 1991). As a consequence a modern, growth-oriented land-use policy should primarily aim at providing attractive locations (not only in terms of quantity but also quality) for high-tech firms, and also to safeguard the local or regional employment level of highly-qualified productive workers in the long run (see also Ponzini and Rossi, 2010).

In this context it should also be borne in mind that network characteristics are nowadays widely considered to be particularly important for innovation and the growth prospects of regions (European Commission,

\footnotetext{
$\dagger$ This paper has been supported by the European Social Foundation (ESF) through the Research and Innovation Monitoring Programme (1.2.0103.11-0005).

* University of Tartu, Narva Road 4, 51009 Tartu, Estonia. E-mail : Peter@mtk.ut.ee

** Ifo Institute, Munich, and University of Applied Management, Erding, Poschingerstr. 5, 81679 Munich, Germany. E-mail : nam@ifo.de

Received : $31^{\text {st }}$ May, 2012 Accepted : $22^{\text {nd }}$ December, 2012

(C) 日本地域学会 (JSRSAI) 2013

${ }^{1}$ For the sake of simplicity we turn to firms of the innovative sector such as high-tech industries, media, science and technology-oriented industries. For more discussions on the term 'innovation' - see Crarayannis, Varblane and Roolaht (2012) and Landry (2012).
} 
2004 ; Hoekman et al., 2009). ${ }^{2}$ Such aspects appear to be more seriously and adequately taken into account when developing an optimal municipal land-use plan, which is effectively combined with the local technology policy. $^{3}$

The provision of adequate spaces for commercial and industrial purposes and setting prices for these in the context of local land-use planning has recently become increasingly important for what is termed location competition among regions and municipalities for attracting innovative firms, since the regional (or local) gap in the provision of some traditional 'hard' infrastructure, including transportation, energy supply, waste disposal facilities, communication systems and so on, has continuously been getting narrower within the country over the course of time. ${ }^{4}$ In addition various types of local policy incentives such as specific tax reductions and direct location subsidies cannot generally be introduced in many advanced countries, since tax competition as such has been limited by fiscal constitution or by EU regulation, for example, as is the case in Germany. Furthermore, many local and regional governments have been suffering from fiscal stress caused by rapidly increasing expenditure over revenue. Although local tax autonomy has long been guaranteed in Germany and other European countries such as Austria and Switzerland, this fact has made local tax reduction less feasible. Local and regional government can also yield extra revenues from the sales of their own (i.e. public) real estate to private firms, for example. Therefore, the municipal policy and the regional competition tend to concentrate on zoning, the provision of suitable land and the creation of industrial parks for attracting firms.

This study aims at investigating the major characteristics of land-use strategies of German municipalities in local competition. As a theoretical basis a two-stage competition model among municipalities is introduced : in the first step an individual model is required to highlight the local economic and interest conflicts within a municipality which emerge when providing high-quality areas for those innovative firms. Secondly, when this internal problem related to the division of land among high-tech and low-tech activities and other uses such as housing, is resolved, municipalities with adequate high-quality industrial areas can compete against each other for the location of high-tech firms within a game theoretical framework (see section 2).

Based on this theoretical background, German case study followed tackles some selected practical aspects of local land-use policy and planning made within the given Germany-specific legal and other institutional framework. First of all, the municipal land-use policy is combined with the typical local industrial policy in this country. Taking Potsdam as example, section 3 demonstrates strengths and weaknesses of the municipality's real estate market facing the fierce competition against each other in attracting high-tech firms, and, at the same time, examines its future chances and risks as the location of different economic activities, which should be adequately taken into account in the local planning process. ${ }^{5}$

${ }^{2}$ In this context innovation is seen as an evolutionary, systemic process resulting from various, associational interactions among a number of actors in a given region, which can also be characterised as social capital (Puttnam, 1993 ; Cooke and Memedovic, 2003). In particular, the concept of agglomeration economies and the incubator hypothesis have been widely applied to explain why the local- and regional-level innovation performance of firms and economic growth are influenced by economies generated by the spatial proximity of the actors (like relations among located firms, research institutions, government agencies, etc.) and associated externalities (Glaeser et al., 1992 ; Mills and McDonald, 1992 ; Fritsch, 2001). Such a close geographical concentration allows for the better exploitation of the 'dynamic relative advantages' in developing the skills and know-how of a given territory (see also Wolfe, 2002).

3 Thus creating a sort of local 'space-oriented' industrial policy the establishment of competent and also competitive local industrial clusters and the creation of innovative branch-mix (also among R\&D-oriented, high-tech industries and modern service firms) will furthermore gain importance when designing the municipal land-use plan and implementing relevant policy strategies (see also McCann, 2007 ; Zwicker-Schwarm et al., 2010).

${ }^{4}$ Innovation safeguards the long-term employment of qualified workers. However, there are also a number of lessdeveloped regions and municipalities in Germany that are suffering from the lack of absorption capacity of innovation activities (Fagerberg and Srholec, 2007). Under such circumstances, an effective land-use strategy alone is not enough to attract innovative firms to these poor regions. In addition many 'one-company' municipalities have traditionally been occupied by labour-intensive manufacturing activities employing mainly less-qualified workers who are locally available.

${ }^{5}$ In land-use planning practice, such classifications are usually made based on the different purpose categories of production sites, such as simple manufacturing areas/logistic locations ; high-quality industrial areas ; scientific, tech- 
The second case study on Technology and Science Park Adlershof in Berlin, demonstrated in section 4, reveals that such industrial parks are nothing but outputs of an integration of local land-zoning and technology policies aimed at creating incubators for innovative SMEs and accomplishing a superior position in a competition (against other municipalities) for those technology-oriented firms.

Furthermore German municipalities not only compete but also look for opportunities to cooperate with each other in order to attract high-tech firms, as is the case with Leipzig (see section 5). In particular, such a strategy appears to be appropriate for small municipalities which suffer from a limited administration and financial capacity when developing and carrying out the local spatial management individually. In addition, inter-municipal cooperation enables them to provide larger sites encompassing territories beyond their own borders and can contribute to a smooth suburbanization process of economic activities in large city areas.

\section{Theoretical approaches to the municipal competition in the real estate provision for the purpose of business promotion}

\section{(1) Municipal competition in zoning}

At the municipal level, the provision of sufficient land and favourable locations for high-tech firms willing to locate themselves (and also to expand) in the municipalities is assessed as crucial for their local development. High-tech industries in particular prefer those municipalities as their locations which are endowed with well-qualified labour, excellent accessibility (also to related modern industries and service firms), as well as a scientific and advanced communication infrastructure, high quality of life and so on (see also Erber, 1995 ; Florida, 2004 ; Landry, 2012). In general one could distinguish two different phases, when examining the municipal competition in terms of the real estate provision aimed at promoting firms' settlement (Friedrich and Lindemann, 2000). The first competition phase relates to land-use planning and the assignment of certain areas as industrial and business districts within a municipality. Although municipalities in Germany possess a high degree of autonomy with respect to the use of their territories, the process of municipal decision-making is highly formalised via special laws (see also below). During the second phase, the planned industrial area is sold to investors by business promotion institutions and industrial parks under the consideration of the restrictions on land prices, which are often fixed through subsidisation policy rules set by the EU, central or sub-national governments. The results are partly considered in the permitted building plan (Bebauungsplan) of the municipality. ${ }^{6}$ A third, revision phase of zoning may follow to evaluate whether the land sales to innovative firms meet the municipality's motivations, expectations and policy objectives or not.

To be sure a planning cycle prevails in this context of land-use development and competition model, in which a dynamic process is involved. However, with respect to zoning competition in the first phase the behaviour in land-use planning of a competing municipality is only assumed by the zoning municipality. It does not negotiate with his competitor. Therefore, at this planning phase an autonomous behaviour of the competitors prevails, which is similar to that widely considered in the static oligopoly models. Before the land-sale to firms takes place, negotiations with other municipalities may occur, e.g. when establishing a joint industrial-park company or planning of jointly-used infrastructure. In the first phase the competition circumstances are more static in terms of competition theory, whereas a competitive negotiation process dominates in the second phase. In the final revision phase the static conditions prevail again (Lindemann, 1999 ; Feng and Friedrich, 2002). ${ }^{7}$ Most literature on zoning does not model the zoning competition among municipalities (Pogoddzinski and Sass, 1990). The models on regional competition usually concentrate on tax competition (Buettner and Ebertz, 2012),

nology and media locations ; etc.

${ }^{6}$ The local building plan which prescribes, for example, the floor number of buildings, the size of green areas, etc. is much more concise than the zoning plan of the municipality in Germany.

7 The municipalities change their zoning with respect to the expected revenues from sales and the realized sales revenues. They also compare the volume of sold and planned industrial area (Lindemann, 1999 ; Friedrich and Lindemann, 2002). They reduce or extent or do not vary their industrial zone. This is considered in the model, which is used to describe the competition in the first phase. 
environmental measures (Oates and Schwab, 1988) and infrastructure competition (Erber, 1995) but hardly deals with municipal competition by zoning or selling land by municipalities. Moreover they seldom consider the different phases mentioned above. For instance, in Germany a local (business) tax preference and concession cannot be provided by municipalities when attracting firms due to the 'equal treatment' principle of taxation. The tax rate can only be changed for all firms existing in a municipality and the federal level is legally responsible for changing tax laws in this country. Therefore, municipalities have to use other means of action (than tax parameters), especially in the second phase of settlement competition. Models are needed to encompass such cases of municipal competition.

Now we start by modelling the first phase of the municipal competition by means of zoning. In our model, land is seen as one of the primary production factors. ${ }^{8}$ Note that the proportion between the planned areas assigned for industrial purposes and the entire territory of a municipality is characterised as the share of local territory dedicated to industrial zones. ${ }^{9} \quad$ The municipalities finance the public production of the municipality (including also public utilities and administration) from tax revenues and the sale of land to settling firms that locate there. ${ }^{10}$ The land revenues of a given municipality depend also on those yielded in a competing municipality. ${ }^{11}$ Production functions exist for private production and the public production within the municipality. ${ }^{12}$ Furthermore, the adoption of cost-minimal production allows for the determination of net private production, land revenues, and public production. ${ }^{13}$ Each municipality fixes its zoning relation $\mathrm{Bp}^{14}$ in such a way to maximize utility, ${ }^{15}$ which is obtained from private and public production under the consideration of the 'dependency' resulting from the zoning of the competing municipality. In this way the utility of both municipalities depends on its own and the competitors' share of industrial zoning.

In the next step the model shows how municipalities maximise their utility in a duopolistic framework, where the zoning percentage $\mathrm{Bp} 1$ and $\mathrm{Bp} 2$ is used as a parameter of action. Municipalities normally act autonomously in competition : one municipality attempts to maximise its utility under the assumption that others do not react (Friedrich, 1977). A Launhardt solution in zoning will then result as depicted in Figure 1, where the reaction lines ${ }^{16} \mathrm{Bp} 1 \mathrm{R}$ and $\mathrm{Bp} 2 \mathrm{R}$ cross each other. ${ }^{17}$

${ }^{8}$ Private production in a municipality depends on labour and land. The production function is of Cobb Douglas type. The public production depends on public municipal employment and a technical production constantly expressing labour productivity.

9 This share is named Bp1 for community 1.

${ }^{10}$ There is a relation stating that the revenues from land sale and tax revenues equal the expenses for public municipal production.

11 For each municipality there is a demand function for expected land sales that depends also on the expected land sales of the competing municipality.

12 See footnote 9 .

13 The tax revenue is linked to the factor income in the private sector. The public municipal sector used this tax revenue to produce municipal production. The input of labor in the private sector is detected by minimizing costs of private production. This information is used to determine the private production and to express the expectation concerning the land to be sold, and the volume of the public production. More details about the model structure and the parameters considered — see Friedrich and Lindemann (2000).

${ }^{14}$ For the municipality 1 we depict Bp1 and Bp2 for the municipality 2 (see Figure 1).

15 The utility of a municipality depends on the volume of the private production and the public production. In Figure 1 the utility of the municipality 1 is expressed by indifference curves that show the highest level at the Bp1 axis. The level of the indifference curves more to the right show descending levels. In analogy develop the difference curves of the municipality 2 .

${ }^{16}$ The reaction line of the municipality $1 \mathrm{Bp} 1 \mathrm{R}$ shows the best $\mathrm{Bp} 1$ if the municipality 2 has fixed its zoning parameter Bp2. The reaction line Bp2R is that of the municipality 2 .

17 In literature one finds different ways to name this solution. In the context of the original 'Launhardt' solution developed by himself price is the parameter of action of duopolists and they sell inhomogeneous products (Launhardt, 1895). Similarly Hotelling uses price as well (Hotelling, 1929). The solution is then named the 'Launhardt-Hotelling' solution. Sometimes authors speak of 'Bertrand-Nash' solution (Neumann, 1994 ; Lambertini and Mosca, 2010). Here the parameter of action is Bp and the zoned space is not homogenous. Still today there are difficulties in naming such a competitive situation. A 'collusion solution' of joint utility maximization is found where the indifference curves are tangent (see also section 5 of this article). If one of the communities 


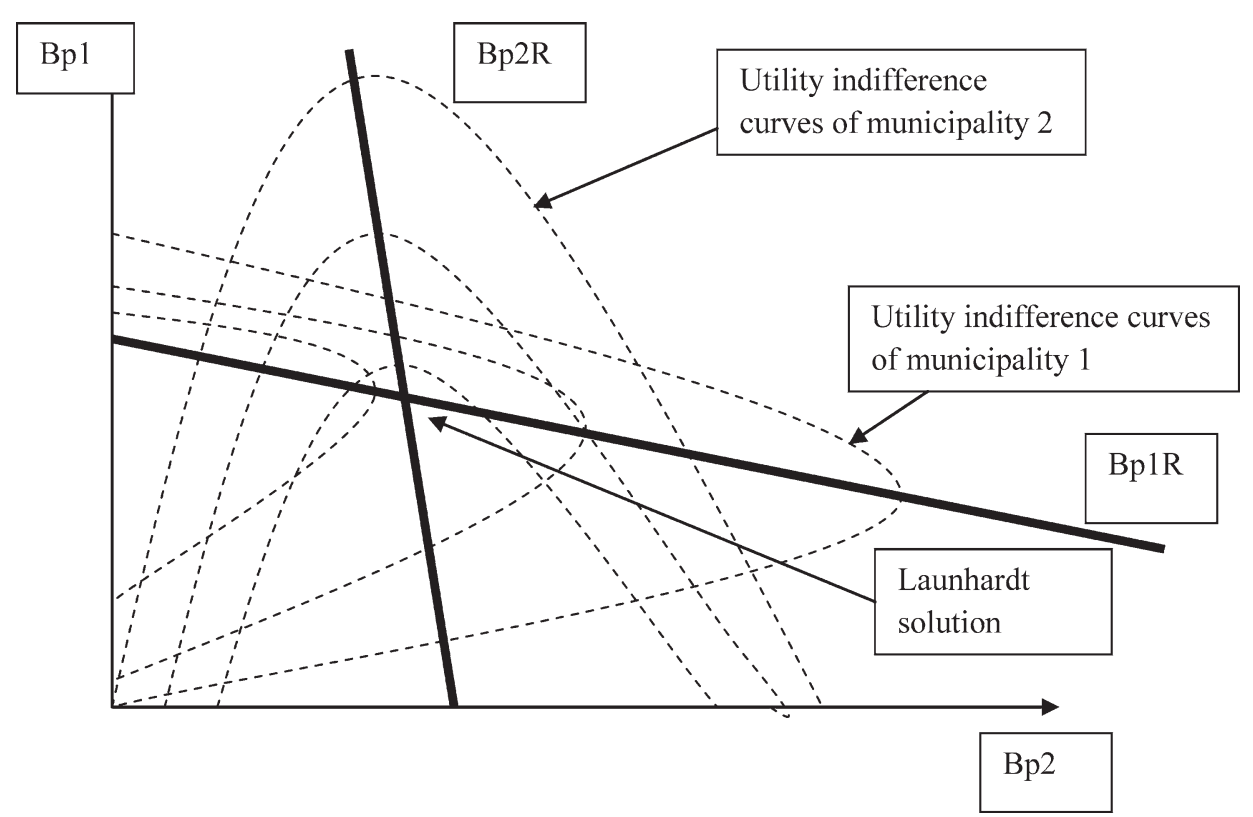

Figure 1. Zoning solution

Source : Similar to Friedrich and Lindemann (2000).

Because of their autonomous behaviour, municipalities tend to plan large zones according to the Launhardt solution. If they were to cooperate together and maximise their common welfare at the collusion point - where the indifference curves are tangential to each other - they would achieve higher utility and plan smaller industrial zones.

When differentiating between the solution formulae for welfare and the zone percentage to the parameters (Lindemann, 1999), one can identify the reactions of the municipalities in zoning competition. Here we concentrate on those of municipality 1 . If the demand for industrial sites for high-tech industries decreases in municipality 1 , the welfare of this municipality also shrinks. In order to compensate for this loss, municipality 1 expands its zone to simulate economic development and to attract low-tech production activities. Consequently, line Bp1R tends to move upwards. If a high preference among high-tech investors for municipality 1 prevails, municipality 1 would provide a large percentage of its territory to high-tech industry : in this case line Bp1R generally shifts upward. If productivity in industry increases due to increased high-tech production, the welfare of municipality 1 (as well as its industrial zone) improves, since line Bp1R moves upwards. ${ }^{18}$ On the other hand, a growth in the level of wages (e.g. in the high-tech sector) is likely to decrease the welfare of municipality 1 , which would react by reducing the proportion of its industrial zone ; and as a consequence the Bp1R line would shift downwards. Higher wages in the public sector will also cause lower welfare for municipality 1 and as a compensatory measure an increase in the industrial area will take place there : therefore the Bp1R curve moves up again.

In addition, through the competitive process municipality 2 is then affected. If the relevant parameters for this municipality also vary, similar changes in local behaviour are also anticipated as is shown in municipality 1 . Yet it should also be borne in mind that higher-tier governments may well influence the local land-use planning and zoning decisions in terms of special grants aimed at creating an industrial zoning pattern in municipalities that match the preferences of those higher level governments. In this case a type of vertical

realizes its independent position a 'von Stackelberg' solution is achieved.

${ }^{18}$ Now there is a downward movement of line Bp2R which strengthens the effect for municipality 1. 
regional competition prevails when determining the zoning patterns in municipalities.

\section{(2) Competition for the location of firms}

If municipal industrial zoning has already taken place, then the battle for the acquisition of high-tech firms starts. Within this zone, private landowners can also sell their real estates to firms that are willing to locate there. However, in order to develop and offer adequate infrastructure and other local utilities and services in a more efficient way, industrial parks are often created, either by the municipality itself or by a joint organisation of business promotion firms and interest groups (such as chambers of commerce, banks, etc.) under the terms of public-private partnership. ${ }^{19}$ For the purpose of demonstrating the ways in which an industrial park can be effectively established, a theoretical approach aimed at forming a coalition can be adopted.

Firstly, the local decision-makers (the municipality or a private joint organisation) have to decide which resources should be dedicated to the industrial park and who joins the industrial park company. Such resources may be expressed in monetary terms (financial means, real estate, existing infrastructure, etc.) and indicated as $x$. The term $x_{i}$ shows the resources brought in by a given decision-maker $i$, while $\Sigma x_{j}(j=1, \ldots, n)$ shows the total resources $x$ dedicated to the industrial park. $X_{R}$ depicts the total resources of all the decision-makers without that of decision-maker $i$. The number of decision-makers is indicated by $n$. Decisionmaker $i$ expects advantages from its engagement in the park if the share of his or her resources in the park increases, because s/he can expand his or her decision-making power in the park company. These advantages are then expressed by parameter $c_{i}$. The dedication of resources by decision-maker $i$ has some negative effects such as opportunity costs, which are captured by parameter $b_{i}{ }^{20}$ Consequently, we obtain a utility function for decision-maker (possible owner) $i$ as follows :

(1) $u_{i}=c_{i} \bullet\left(x_{i} / \Sigma x_{j}\right)-b_{i} \bullet x_{i}$

(2) $X_{R}=X-x_{i}$

(3) $u_{i}=c_{i} \bullet\left(x_{i} /\left(x_{i}+X_{R}\right)\right)-b_{i} \bullet x_{i}=c_{i} \bullet\left(1-X_{R} /\left(x_{i}+X_{R}\right)\right)-b_{i} \bullet x_{i}$

The decision-maker intends to maximise his or her utility by cooperating with other stakeholders and s/he himself becomes a shareholder. We assume that the decision-makers choose an 'autonomous strategy', which in turn, means that one decision-maker maximises its utility under the assumption that others do not react to this offer. In other words, the same decision-maker assumes that the offers $X_{R}$ from the other actors do not change. This solution refers to an approach by Cornes and Hartley (2001). The maximisation of the utility function (3) takes place, ${ }^{21}$ when

(7) $X=\left(c_{i} / b_{i}\right) \cdot\left(1-\left(x_{i} / X\right)\right)$

According to equation (7), a decision-maker's (= possible owner's) optimum share of resources in a park turns out to be :

(8) $x_{i} / X=1-\left(b_{i} / c_{i}\right) \cdot X$

Hence, the optimal number of owners forming the park company and an adequate volume for $X$ is determined where the sums of the values of the optimal shares add up to one. To participate in an industrial park the cost/benefit ratio must be smaller than the average of the sum of other members of the park company. Those

19 See section 4 of this article.

${ }^{20}$ Other forms of $b_{i}$ can be treated as well.

${ }^{21}$ (4) $d u_{i} / d x_{i}=c_{i}\left(X_{R} /\left(x_{i}+X_{R}\right)^{2}\right)-b_{i}=0$

(5) $X^{2}=\left(c_{i} / b_{i}\right) \cdot X_{R}$

(6) $X^{2}=\left(c_{i} / b_{i}\right) \cdot\left(X-x_{i}\right)$ 


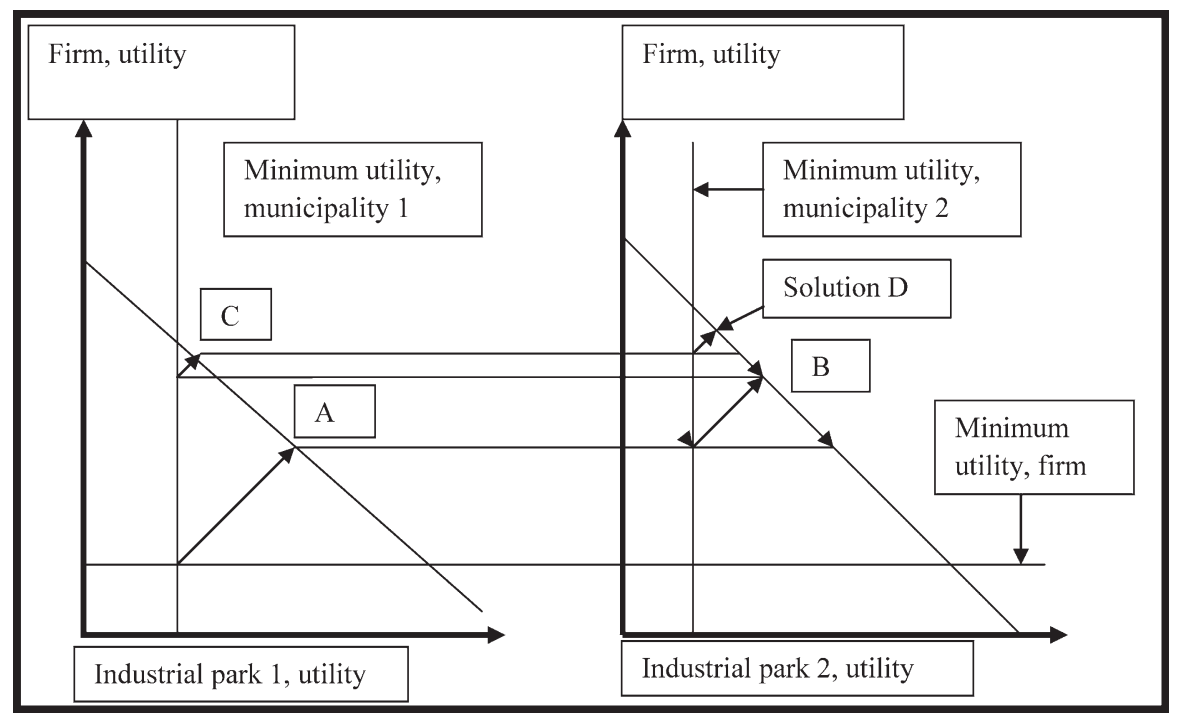

Figure 2. Supply-restricted monopsony Source : Feng and Friedrich (1999); Batey and Friedrich (2000); Friedrich and Nam (2009).

decision-makers who are not willing to join have high $c$ parameters on the one hand and low opportunity costs $b$ on the other.

After the industrial park is established the company managing the industrial park starts to sell plots of land to high-tech firms. This will be illustrated by a sales model. We now adopt a supply restricted monopsony model, which demonstrates that two industrial parks in different municipalities compete against each other for one high-tech industrial firm (Feng and Friedrich, 1999; Batey and Friedrich, 2000 ; Friedrich and Nam, 2009). Assume that the industrial park is willing to achieve high utility, which in turn, depends on the volume of production of the new firm, its employment, the capital investment of the firm, the revenue from the real estate sale (expressed e.g. in terms of high real estate price) and a 'performance-oriented' subsidy (or land price discount) that increases with the firm's production volume. The locating high-tech firm maximises its net profit by facing a demand relation, production function and cost function. A set of possible contracts is determined, which is related to the distribution of utilities in the park and the locating firm. This leads to a utility possibility curve, which is reflected in the descending line on the right hand side of Figure 2 . Out of these possible utility distributions and corresponding contracts, a Nash solution for location negotiations is found at point $\mathrm{A}$ in the same figure. ${ }^{22}$ Minimum utilities pointing to opportunity benefits, which are realised if no contract is concluded, are also considered (e.g. from a locating non-high-tech firm or some service business instead of high-tech firms).

The competition process is illustrated in Figure 2. Industrial park 1 (in municipality 1 ) finds an initial solution with the firm at point A. Then the firm negotiates with industrial park 2 in order to improve its utility, taking the utility level resulting from point $\mathrm{A}$ as a yardstick for minimum utility. The next superior negotiation solution for the firm is then point $\mathrm{B}$, followed by renegotiations with municipality 1 , again using the utility level achieved with industrial park 2 as a minimum utility delivered at point $\mathrm{C}$. Furthermore, another negotiation round follows based on the new minimum utility of the firm gained at $\mathrm{C}$, which leads to the final

${ }^{22}$ By differentiating the parameters of the solution formulae, one can determine how changes in production functions of high tech firms, factor prices, changes in demand for high tech products, in pre-services and their prices delivered to high tech firms by the industrial park, changes in the utility function of park management or municipalities influence the solution and the size of the land price (Feng and Friedrich, 1999; Lindemann, 1999; Friedrich and Lindemann, 2000). 
solution. Here the minimum utility of the firm gets so high that industrial park 1 cannot offer another superior option since the industrial park has reached its minimum utility and, due to this reason, stops further negotiations. From one step to another the real estate price shrinks and the utilities of both industrial parks continue to decline, whereas the utilities of the firm increases until one industrial park gives up. Disappointing results of such firm-oriented competition may initiate further changes in the zoning of municipalities that can be explained by an extension of the two approaches mentioned here to an adaptation model (see Lindeman, 1999 ; Friedrich and Lindeman, 2000). ${ }^{23}$

If municipalities compete for a high-tech firm, the successful municipality would be the one which offers an industrial park and local conditions that fit the high-tech firm best and where the high-tech firm allows the winning municipality a large space with a utility frontier that is way over to the right in Figure 2. The size of minimum utility can also be reflected in the fact that a municipality can evaluate other opportunities ; for example, the possibility of attracting low-tech manufacturing companies. If there are fewer opportunities to attract such low-tech firms, the minimum utility of the municipality tends to be low and its vertical curve runs further to the left in Figure 2 (see the case of municipality 2). Consequently, this municipality can participate in more rounds of the competition process. ${ }^{24}$ On the other hand, if a rather high minimum utility can be achieved in the context of the location of low-tech manufacturing activities, which in turn weakens the position of the high-tech firm, the process will stop earlier. In this case the locating firm is not able to exploit the community to any considerable degree. In Figure 2, the negotiation process stops further to the right, where the firm achieves less utility. The price for the real estate will turn out to be higher in this case. ${ }^{25}$

The industrial land and the municipal territory are inhomogeneous goods. This leads to the zoning model that shows the Launhardt solution. For the zoning decision made in the framework of a German landuse plan these inhomogeneous spatial features are captured only roughly : individual plots of land are not regulated in detail in this institutional framework while the land-use classification primarily takes place in terms of industrial purposes, housing, general public use, mixed purposes, etc. This fact is considered by the first model where only the decision about the percentage of territory which is dedicated for industrial purposes is determined. Moreover the land has various attributes in the sense of Lancaster (1966), thus making it even more inhomogeneous because it is differently useful according to the public and private activities, since the user of land perform in various ways. This aspect becomes more essential, if the municipality plans to establish an industrial park, where the land and its attributes as well as infrastructure must be related to types of industries, e.g. high-tech industries, to be attracted. This is considered in the second model within the utility functions of the decision-makers, which present the usefulness of the industrial land for their purposes.

As the utility of the park stakeholders turns out to be different with respect to the land use, it is also reflected, whether the land and the park are seen as appropriate to attract high-tech industries. ${ }^{26}$ The attributes of land are intensively considered in the sales model and they determine the solution space for the negotiations. If the industrial park company (municipality) expects high utility from the land use by a special firm, the solution space for negotiations of industrial park 1 with that firm is located more to the north-east in the utility diagram in Figure 2. If the firm expects high profits from locating in that park the solution space shifts to the north-east in the same figure and the position of that park in municipal firm settlement position turns out to be strong as it can win the competition for firm 1 more easily. ${ }^{27}$ The production function of the

${ }^{23}$ Empirically observed adaptations of zoning are mentioned in section 4.

${ }^{24}$ In Figure 2, the minimum vertical utility line of municipality 2 is located further to the left than that of municipality 1 . The solution space for municipality 2 increases as the triangle between the minimum utility curve and the utility possibility curve increases (e.g. in the right section of the municipality in Figure 2). Moreover, municipality 2 achieves less utility out of the last round and achieves a lower land price. If the move of the minimum line is with the other municipality in Figure 2, its solution space might increase and it can stand more competitive rounds with the effect that the utility of the winning municipality is reduced and the land price lower.

${ }^{25}$ If the right firm presents a minimum utility line further to the right, the solution process stops earlier (here after one round, if the move is big) and the firm cannot achieve a lower land price and higher utility.

${ }^{26}$ See equation (1) in section 2.

${ }^{27}$ See text explaining Figure 2. 
firm and the factor prices may also be influenced by agglomeration, access to pre-services, transportation, tax rates, etc., such phenomena are however tackled rather implicitly in this study. As the following examples in next sections show, they are of interest when looking at features of a city as a high-tech location, but they are only partly related to the parameters of action, which a city can take in municipal competition.

The same is also true with respect to external effects. External spill-overs may lead to that greenbelts become necessary, for example. In this case special public production is required to manage such green areas and the utility of the municipal public production turns out to be higher in the first model. Positive external effects for firms may also be reflected in the parameters of the expected demand function for land during the zoning phase. Concerning the industrial park model such external effects can be expressed in the utility functions of the stakeholders. The sales model reflects external effects as well : with positive external effects the profits of firms and the solution spaces might increase. However, many external effects cannot be influenced by municipal policy alone or they are linked to unchangeable environmental and geographic conditions. In the context of our model we primarily focus on those consequences on municipal location competition which are related to the provision of land and zoning activities.

\section{Land-use strategies for attracting innovative firms in German municipalities}

During the cycle of municipal competition by zoning and land sale to companies the real estate demand stems from the following individual motives :

- The need for established firms to expand their capacity ;

- A firm's dissatisfaction caused by the shortcomings and comparative disadvantages of their existing location ('relocation') ;

- Strategic location decisions made by multinational firms ; and

- New start-ups.

It is clear that demand is often determined by a combination of such motives. Furthermore, just like the continuous shortening of a product life cycle, the life cycle of industrial sites and commercial buildings has also been getting increasingly shorter over the course of time. Yet, according to Grabow et al. (1995) and MSWV (2002), the relocation of German firms in a given city usually takes place within a short distance ; for example, either within the city borders or to its immediate neighbouring areas.

Due to the general spatial limits, it has traditionally been a difficult task to resolve the conflict in most German cities and municipalities between land-use for housing on the one hand, and commercial and industrial purposes on the other (see also Lehmann-Grube and Pfähler, 1998 ; Friedrich and Lindemann, 2000 ; Blume, 2003). In many large German cities, commercial and industrial sites are categorised according to their different uses as follows :

- Simple manufacturing areas/logistics locations ;

- High-quality industrial areas ;

- Locations for light manufacturing and craft ;

- Scientific, technology and media locations ; and

- Integrated urban areas for offices.

All these locations differ from one type to another in terms of site size required for production and other related economic activities, intensity of environmental disruption, urban or rural quality, road and public transport connections, proximity to research firms and/or large international firms, etc. (Zwicker-Schwarm et al., 2010).

Taking Potsdam, the capital of Brandenburg, as an example, Table 1 and 2 demonstrate the strengths and weaknesses (and constraints) of the city's real estate market as well as its future opportunities and threats as a location for different economic activities. The classification has been made based on the different purpose categories of production sites shown above. 
Table 1. Development of industrial and commercial sites in Potsdam : strengths vs. weaknesses

\begin{tabular}{|c|c|}
\hline Strengths & Weaknesses \\
\hline $\begin{array}{l}\text { Quality of industrial site as a location in general } \\
\text { - Solid economic and structural base for development } \\
\text { - Excellent image of the city as a science and modern } \\
\text { service centre combined with high-quality of living } \\
\text { - Regional policy eligibility (e.g. former Objective } 2 \\
\text { region in the EU) } \\
\text { - Availability of substantial areas as potential sites for } \\
\text { production } \\
\text { - Urban and integrated industrial areas for modern com- } \\
\text { mercial uses }\end{array}$ & $\begin{array}{l}\text { Quality of industrial site as a location in general } \\
\text { - Very high price in the local real estate market } \\
\text { - The city government possesses very few unused areas } \\
\text { which can be further developed as industrial sites. } \\
\text { On the other hand, private ownership of potential sites } \\
\text { is dominant } \\
\text { - Some modern service functions like logistics parks } \\
\text { and suitable sites for such functions are not prevalent } \\
\text { in the city } \\
\text { - Inner-city traffic connections somewhat problematic } \\
\text { (e.g. Nadelöhre Havelbrücken) } \\
\text { - Relatively poor nationwide railway connection }\end{array}$ \\
\hline $\begin{array}{l}\text { Science, technology and } R \& D \text {-oriented firms } \\
\text { - Strong research base in cooperation with competent } \\
\text { R\&D-oriented firms } \\
\text { - Existence of locations with technology competence } \\
\text { and agglomeration advantages (including Medienstadt } \\
\text { Babelsberg, Wissenschaftspark Golm, Telegrafenberg) } \\
\text { - Supply of various types of potential sites for technol- } \\
\text { ogy and incubator centres }\end{array}$ & $\begin{array}{l}\text { Science, technology and } R \& D \text {-oriented firms } \\
\text { - Acute spatial shortage (also anticipated to prevail in } \\
\text { the medium term future) in the high-quality R\&D-ori- } \\
\text { ented locations, in particular for research institutions } \\
\text { and new start-ups in areas like Telegrafenberg, Medi- } \\
\text { enstadt Babelsberg, Wissenschaftspark Golm, etc. }\end{array}$ \\
\hline \multirow[t]{2}{*}{$\begin{array}{l}\text { Manufacturing firms and crafts } \\
\text { - Crafts sector an important part of the local economy } \\
\text { - Existence of a large number of strongly environment- } \\
\text { oriented manufacturing firms in the city, which would } \\
\text { possibly attract the location of more technology-ori- } \\
\text { ented firms there }\end{array}$} & $\begin{array}{l}\text { Manufacturing firms and crafts } \\
\text { - Serious impediments presently exist in spatial expan- } \\
\text { sion for simple manufacturing activities } \\
\text { - Huge up-grading and improvement needs for estab- } \\
\text { lished industrial locations like Potsdam-Süd (also in } \\
\text { terms of infrastructure) } \\
\text { - Supply deficit of suitable production areas and other } \\
\text { sites for their related activities (e.g. factories and } \\
\text { warehouses at reasonable prices/rents) } \\
\text { - Less intensive public care and maintenance for exist- } \\
\text { ing industrial sites }\end{array}$ \\
\hline & $\begin{array}{l}\text { Local land-use policy related to the provision of industrial } \\
\text { sites } \\
\text { - Too strong a focus on attracting new firms from out- } \\
\text { side, while somehow neglecting the need for industrial } \\
\text { sites for indigenous firms located in the city } \\
\text { - Information deficits related to the supply of sites for } \\
\text { production purposes } \\
\text { - Insufficient support from local authority in project } \\
\text { development (unclear communication related to plan- } \\
\text { ning possibilities, etc.) }\end{array}$ \\
\hline
\end{tabular}

Source : Authors' compilation from Zwicker-Schwarm et al. (2010).

\section{Technology park : a strategic mixture between land-use policy and local technology policy}

In the context of regional and/or local technology policy, technology and innovation centres in many countries have sought to play an incubator role in the establishment of new innovative SMEs. In other words, the policies of such high-tech centres focus on the mobilisation and enhancement of local technological and industrial resources and are mainly targeted at creating small new technology-based firms. For example, in Germany, in the context of public-private partnership, local authorities (i.e. city or municipal governments), private firms and the local Chamber of Industry and Commerce (IHK) are generally the major sponsors in the development of 
Table 2. Development of industrial and commercial sites in Potsdam : future opportunities and risks

\begin{tabular}{|c|c|}
\hline Opportunities & Risks \\
\hline $\begin{array}{l}\text { Quality of industrial site as a location in general } \\
\text { - Favourable development prospects (in particular posi- } \\
\text { tive demographic and labour market forecasts) } \\
\text { - Improvement of location quality through the opening } \\
\text { of the new Berlin Brandenburg International Airport } \\
\text { (BBI) } \\
\text { - Increasing significance of 'soft' infrastructure and its } \\
\text { endowment in the city }\end{array}$ & $\begin{array}{l}\text { Quality of industrial site as a location in general } \\
\text { - Some difficulties in developing industrial and commer- } \\
\text { cial sites, due in part to the fiscal stress from which } \\
\text { Potsdam has been suffering } \\
\text { - Spatial competition, not only with the surrounding } \\
\text { municipalities which offer lower-cost industrial sites } \\
\text { than the city does, but also with Berlin in terms of } \\
\text { modern offices }\end{array}$ \\
\hline $\begin{array}{l}\text { Science, technology and } R \& D \text {-oriented firms } \\
\text { - Growth and concentration of firms in areas of biotech- } \\
\text { nology, life science and media, for which Potsdam } \\
\text { already has comparative advantage } \\
\text { - Further improvement of location quality for firms } \\
\text { related to green production, environmental protection } \\
\text { and climate change, etc. } \\
\text { - Attractive business environment for high-tech firms } \\
\text { (in terms of economic and sector-specific features and } \\
\text { infrastructure) }\end{array}$ & $\begin{array}{l}\text { Science, technology and } R \& D \text {-oriented firms } \\
\text { - Possible drifts of spin-offs caused by the lack of suit- } \\
\text { able (and attractive) production sites (also for expan- } \\
\text { sion) } \\
\text { - Insufficient exploitation of spatial potential for the new } \\
\text { location of firms } \\
\text { - Strong nationwide competition for location, particu- } \\
\text { larly in the media sector }\end{array}$ \\
\hline $\begin{array}{l}\text { Manufacturing firms and crafts } \\
\text { - Growing market for local and regional products and } \\
\text { services }\end{array}$ & $\begin{array}{l}\text { Manufacturing firms and crafts } \\
\text { - Deindustrialisation and continuing decrease in the } \\
\text { number of jobs in German industries, including the } \\
\text { automotive sector } \\
\text { - Transformation and regeneration of old industrial sites } \\
\text { within the city for other purposes such as residential } \\
\text { areas } \\
\text { - Termination and relocation of business caused by } \\
\text { insufficient supply of sites }\end{array}$ \\
\hline $\begin{array}{l}\text { Services } \\
\text { - Continuous internationalisation of services and research } \\
\text { activities, as well as the intensification of global tech- } \\
\text { nology network } \\
\text { - Growth of service sector, especially the business-ori- } \\
\text { ented service firms, in Germany }\end{array}$ & \\
\hline
\end{tabular}

Source : Authors' compilation from Zwicker-Schwarm et al. (2010).

these centres. They are special types of industrial parks treated in the model above. All these ambitious projects have been accompanied by local innovation-oriented land-use policy, since such technology parks usually need ample land, the provision of which is often difficult. For a limited period (usually three to five years), German innovation centres provide offices and other commercial facilities at affordable rents to make the establishment of technology-oriented firms easier (Sternberg, 1995). Even for those municipalities and regions faced with a high concentration of older, declining industries, these innovation centres have been assessed as a tool for facilitating economic restructuring through the incubation of new-technology-based SMEs (Rothwell, 1986 ; Gray, 1992 ; Nauwelaers and Wintjes, 2000).

A number of previous studies evaluating the effectiveness of German innovation centres as instruments of combining land-use policy together with local innovation policy aimed at achieving technology-led economic development have generally been positive about the support given to start-up firms, the value added to the local economy (especially in old industrial areas) and the so-called multiplier effects derived from the concentration of highly-qualified professional employment in those centres (Fiedler and Wodtke, 1991 ; Steinkühler, 1994). On the other hand, the geographic size of German innovation centres is relatively small, compared to the more spatially-concentrated ones in the United States and France - a fact which also indicates the 
shortage of high-quality spaces for industrial and commercial purposes in this country. Nevertheless, many centres in Germany do not fully utilize the capacity of commercial sites for new firms as turned out also from the zoning model described above. In addition, assessments have largely shown that the employment effects on the local and/or regional labour market led by incubator activities are less important than expected, partly because many of the centres dispersed all over the nation are relatively small (see also Sternberg, 1995). This also results from the sales model discussed above due to the many supplying municipalities and the restricted number of high-tech firms and start-ups looking for a site. Yet the recent development of the Technology and Science Park Berlin Adlershof appears to be somewhat different and promising (see below).

In many cases technology and industrial parks have not developed along lines originally planned. As a consequence the economic and social benefits of such a project often tend to differ largely from than anticipated. These facts are well indicated by the development of a number of technology centres into industrial monocultures, rather than into the well-balanced and highly diversified industrial parks envisaged by the planners. The phenomenon is due in part to a number of complex sociological and economic reasons. To a larger extent, the successful development of a technology park also seems to be led by the ability and flexibility of the operating authorities to react to changing (particularly economic and sector-specific) circumstances, to make the necessary mid-course corrections, and, more generally, to develop an effective evaluation and problem-solving mechanism.

\section{Case study: Technology and Science Park Berlin Adlershof}

As a district, Adlershof belongs to the eastern part of Berlin. ${ }^{28}$ Embedded in an overall urban development concept for the city of Berlin, this integrated science, business and media centre was established in an area of $4.2 \mathrm{~km}^{2}$ in 1991 . In close proximity one can also find shops, hotels, restaurants and a park of 66 hectares.

Adlershof has traditionally been a scientific centre pursuing intensive cooperation with industry. In particular, the East German Academy of Science (founded here in 1946 with nine scientific institutes in the fields of physics and chemistry) made decisive contributions to inventions. After unification the former Academy was reorganised and territorial conversion took place in Adlershof for modern use : real estates were made available. Since the establishment of the Adlershof Technology and Science Park in 1991, a total of 1.3 billion euros of public funds (provided by Berlin as well as the German federal government) has been invested in the development area's infrastructure and its industrial and commercial facilities (see DIW, 2010).

Based on its historical strength, the major goal of the project was to generate synergies from science and industry, bridging innovation and the market via appropriate applications. In order to encourage innovative businesses to locate there, several modern specialised centres were established, utilising comparative advantages : the first was the Innovation and Business Incubation Centre (IGZ) in 1991, followed by the Centre for Photonics and Optical Technologies, the Centre for Environmental, Bio and Energy Technology, the Centre for Information and Media Technology, and the Centre for Materials and Microsystems Technology. ${ }^{29}$

At the end of 2010, 883 companies, scientific institutes and other types of institutions were based in Adlershof - an increase of 47 on the previous year. Amounting to 2.1 billion euros, business revenues (including financial coverage for scientific institutions and subsidies made by governments) rose by $21 \%$ compared to the previous year. The number of people employed at Adlershof rose by $4.1 \%$ to more than 14,000 . Table 3 shows the classification of the total business performance of Adlershof according to individual core activities.

The regional economic analysis carried out by DIW (2010) demonstrates that :

- Over 1 billion euros of gross value added (GVA) was generated directly in Adlershof in 2010. In addi-

${ }^{28}$ It is connected to Highway 113, which runs from just north of Berlin-Schönefeld Airport to Dresden. The transport situation in the district will be further improved by the expansion of the railway underpass in Adlergestell/Rudower Chaussee, while the expansion of the tram connection between the subway station and Campus Adlershof is under construction. The road connection between Groß-Berliner Damm and Schöneweide is also favourable.

${ }^{29}$ See more detailed information and facts at http://www.adlershof.de/. 
Table 3. Business performance of Adlershof classified by its core activities in 2010

Science and Technology Park

Number of companies : 425, of which 46 new additions in 2010

Number of employees : 4,908

Total annual turnover : 580.2 million euros (including the share of government subsidies of $6.4 \%$ )

Non-university scientific institutions (11 institutions)

Number of employees : 1,701

Total annual basic funding : 119.5 million euros (including third-party funding of 53.4 million euros)

Institutes of the Humboldt University of Berlin (Institute for Computer Science, Mathematics, Chemistry, Physics, Geography and Psychology)

Number of employees : 925

Number of students : 7,874

Total annual basic financing : 39 million euros (including third-party funding of 20.5 million euros)

Media City

Number of companies : 139

Number of employees : 1,734 (including freelancers)

Total annual revenue : 176.7 million euros

Related Trade and services

Number of companies : 302

Number of employees : 5,000

Total annual revenue : 1.2 billion euros

Source : http://www.adlershof.de/datenfakten/?L=2.

tion to that, a further 740 million euros in GVA in other parts of Berlin was indirectly triggered by Adlershof.

- In 2010, over 14,000 people were directly employed in Adlershof as already mentioned above. For every employed person in Adlershof there was another employed person in other parts of Berlin who depended on the former, so that the overall effect was just below 28,000 employed people.

- In 2010, Adlershof triggered 340 million euros of tax revenue, around 180 million of which remained in the state of Berlin.

- Since 2005 Adlershof has been growing rapidly. This applies to both sales $(+10.9 \%$ per year $)$ and GVA $(+7.2 \%$ per year) and for tax revenue $(+7.1 \%$ per year $)$ and the number of employed people ( $+3.8 \%$ per year). These values are well above the comparable figures for Berlin or Germany.

Moreover, calculations based on the potentially available space in Adlershof indicate that a further growth in employment of up to 18,800 jobs is possible in the future. If innovative and high-growth companies from future-oriented industries consistently continue to locate there, it is likely that the existing, above-average growth trajectory will be maintained and the area capacity of the technology park will be fully utilised between 2025 and 2033 (see DIW, 2010).

\section{Inter-municipal cooperation in the innovation-oriented land use policy}

A close inter-municipal cooperation in space management not only generates positive synergy effects in providing larger sites encompassing territories beyond their local borders, but also strengthens the position of the local entities involved in the fierce competition against other regions in attracting innovative firms (Blume, 2003). In addition such cooperation between a large city and its surroundings can contribute significantly to a smooth suburbanisation process of economic activities in the entire urban areas. In this context, the core cities which generally suffer from a lack of space can better provide the opportunities for spatial expansion for those well-performing local firms in the cities, while the surrounding municipalities can also benefit from attracting modern industrial and service activities in terms of spin-offs and related positive external effects. This would be one of the ideal ways of creating the region-specific (inter-municipal) clusters of 
innovative firms and industrial mix in relatively large enclaves, which are well-endowed with existing hard and soft infrastructure already provided by the core cities.

\section{Case study: The CITYREGIO project of the Leipzig region}

The City of Leipzig and its surroundings (Landkreis Delitsch, Leipziger Land and Muldentalkreis) developed a cluster-oriented location management system within the scope of the common initiatives INTERREG III B (EU Cooperation Area CADSES). In the context of the CITYREGIO project, which ran from 2003 to 2005, this inter-municipal cooperation aimed to seek and implement a series of measures required for the development of local economic clusters and location information system for 'car and ancillary industry'; 'environmental technology and energy' ; and 'health and recreation services' (Dressen, 2004).

This project was originally initiated by local authorities, based on their acknowledgement that the traditional location competition for new industries and service activities between the centre and its neighbouring municipalities has caused difficulties and frictions, which have not only caused difficult relationships but also seriously hindered the promotion of balanced economic development between the two areas. In particular, badly-coordinated land-use planning for industrial and commercial sites has led to an excessive overall supply of sites in the Leipzig region but has failed to satisfy the specific demands of local and other innovative firms. The CITYREGIO Leipzig project strongly emphasised the negative effects of such shortcomings on local and regional development and attempted to develop a cooperative pan-regional land-use policy to attract (innovative) firms to locate and to strengthen the economic competitiveness of the entire region.

The principal tasks of the project were (i) coordination of land-use design and spatial development for industrial sites ; (ii) harmonisation of the development strategy options between the core city and its surroundings (for example, in location marketing) ; (iii) enhancement of the knowledge base of endogenous economic potentials of the municipalities involved and the entire region; and (iv) improved cooperation between firms and local administrations (at the regional level) in the creation of a regional cluster (Dressen, 2004).

The city/surroundings cooperation carried out an analytic task and some realisation-related activities. To the former task belong, for example, the analyses of economic and population structure, and the location system of the individual entities as well as their city/surroundings relations and the endowment of potential human resources. Based on the location and branch analyses, which are strongly oriented to the creation and/or expansion of clusters, necessary information and know-how was collected in order to systematically improve the regional economic environment for the selected industrial branches and to better coordinate the spatial development strategy of local authorities at the regional level.

Some activities were also defined as 'regional' tasks, which include, for example :

- The development of regional location and branch information systems for the economic location cluster ;

- Regional location management (one-stop agency);

- Planning support and investment-preparation measures for industrial and commercial sites (with high priorities for sustainable economic cluster development) and for cluster support measures (training, traffic and infrastructure plan, etc.) ;

- The establishment of regional networks among actors such as enterprises, chambers of commerce, local administrations, etc. and scientific consultation and training for the regional actors in the network ;

- Regional location marketing; and

- Dissemination of project results and experiences as well as further recommendations for future use by other conurbations of the CADSES space (Dressen, 2004).

With all these measures, the project partners attempted to (a) achieve better mobilisation and interlinking of endogenous regional economic potential, which has been insufficiently exploited up to now, (b) make the entire region more attractive for investors, (c) improve the regional labour market situation, and (d) strengthen the competitiveness of the firms located in the region.

However, such kinds of cooperation have to overcome difficulties of implementation. There are hinder- 
ing factors such as the prohibition of donations between municipalities, a non-existing horizontal equalization among municipalities, the difficulties of arranging compensations between the municipalities cooperating, the fear to lose competences or the loss of independency in future territorial reforms, and the loss of democracy if a special purpose association of public law gets established. ${ }^{30}$

\section{Conclusion}

This study highlights the role of land-use policy in location competition between German municipalities and attempts to investigate the major characteristics of their strategies, which are aimed at attracting innovative firms under the particular consideration of their own local preferences and the aspect of innovation networks and clusters. Strongly based on the subsidiarity principle, local land-use policy is usually combined with the typical local industrial and innovation policy in this country. In this context, German municipalities can have an impact on the local economic structure, since they set the extent to which the available sites in their own territories can be distributed for different purposes such as production, housing, transportation, green areas, etc. and they sell land to investors. By doing so, they can also encompasses all these different land-use purposes in a systematic manner but also generates the maximum use of positive external effects (see the Potsdam case).

Those large-scale industrial parks, such as the Technology and Science Park Adlershof in Berlin, are seen as a strategic mix of local land-use and technology policies designed to create incubators for innovative SMEs with ample space and to accomplish a superior position in the competition (with other municipalities) for those hightech firms. Such industrial parks generate the synergies from science and industry, bridging innovation and the market via appropriate applications.

Furthermore, German municipalities like Leipzig and its surroundings not only compete against each other but also, at the same time, look for opportunities to cooperate in order to attract innovative firms. Major cooperation issues include, for example: (a) coordination of land-use design and spatial development for industrial sites ; (b) harmonisation of the development strategy options between the core city and its surroundings (for example, location marketing) ; (c) enhancement of the knowledge base of the endogenous economic potentials of the municipalities involved as well as the entire region; and (d) improved cooperation between firms and local administrations (at the regional level) in the creation of regional clusters and so on.

Such German-style sub-national innovation-oriented land-use strategies and the competition behaviours of municipalities can be well demonstrated by a 'theoretical' two-level municipal competition model, as shown in this study. The municipalities compete in the first phase of land-use planning and zoning within their territories (see the case of Potsdam). After having decided on the size and character of their industrial zone, they enter the second stage of municipal competition for the location of firms by establishing industrial parks. In this competition, the planning of the size and quality of the land in the industrial zone, as well as its sales strategy, plays a crucial role. This competitive aspect among municipalities is also revealed in the legal and institutional frameworks in Germany.

The empirical research finding coincides with a zoning model that illustrates the oligopolistic competition between municipalities that aims to attract high-tech firms. The model makes it possible to suggest the direction of changes in zoning if there is a shift in relevant factors such as preferences for high-tech firms, factor endowments and prices as well as demand for industrial plots among high-tech firms. The solution also demonstrates that there is a tendency for large industrial zones related to the size of the municipalities, whereas it also points to municipal welfare improvements led by inter-municipal cooperation like the CITY-

${ }^{30}$ The provisions of solid, institutionally-backed managerial foundation with own decision-making power for those municipalities in cooperation appears to be rather difficult in Germany. In particular such problems emerge if inter-municipal industrial parks are created: specific agreements between municipalities about territorial changes, public contracts about feasible horizontal fiscal compensation between municipalities, etc. are necessary usually (Lindemann, 1999). Approval by the respective state to which the municipalities belong is also required : especially if those cooperating municipalities stem from different states, this becomes more difficult. For the cross-border local cooperation within the EU, European company forms such as European Grouping of Territorial Cooperation (EGTC) can also be suggested (see European Commission, 2006). 
REGIO project in Leipzig. This fact suggests that the described competition model can also be modified and further developed through the consideration of some additional determinants that are relevant for cross-border municipal cooperation.

In order to be well prepared for location competition among high-tech firms, municipalities tend to establish industrial parks. A theoretical model which explains the formation of such a park by municipal and private decision-makers is also demonstrated. The municipal benefits $c_{i}$ are closely linked to the municipality's share in the resources of the park $x_{i} / X$. The parameter $b_{i}$ reflects the opportunity costs caused by its engagement. Furthermore, the model demonstrates important factors in the outcome of the negotiation in the form of a location contract ; for example, in terms of land price, firm outputs, subsidies and so on, and the change in land price if the evaluations of the municipality, the market conditions of the locating firm and the infrastructure endowment change. These factors are well highlighted in the case studies concerning Potsdam and Berlin Adlershof.

The process of location competition is shown in the study in terms of a simple supply-restricted monopsony model. Its outcome illustrates that the competition between industrial parks for a high-tech firm tend to lead to relatively low land prices. An exploitation of the municipalities is involved as they receive less utility than without municipal competition. Moreover, it points to the tendency that industrial parks such as Berlin Adlershof with its infrastructure endowments attract particularly profitable high-tech firms. Such circumstances allow for a large solution space for the negotiators. Those municipalities, which are not sufficiently equipped with infrastructure and favourable location factors, have a small solution space. They are likely to lose in the competition and should be satisfied with the location of traditional industries and services.

The model approach made in this study primarily focuses on the parameters shaping zoning and land-use at the municipal level. The demonstrated competition model could be extended by considering other parameters of clustering more explicitly, such as supply relations between firms, connecting infrastructure including product lines, shareholding networks, support programmes for other public actors and zoning revision.

\section{References}

[ 1 ] Batey, P. and Friedrich, P., "Aspects of Regional Competition,” in : Batey, P. and Friedrich, P. (eds.), Regional Competition, Heidelberg : Springer, 2000, pp. 3-33.

[ 2 ] Blume, L., Kommunen im Wettbewerb, Baden-Baden : Nomos, 2003.

[ 3 ] Buettner, T. and Ebertz, A., Urban Sprawl and Interjurisdictional Competition, Paper presented at the IEB Workshop II on Urban Economics, June 2012, Barcelona, mimeo.

[ 4 ] Carayannis, E.G., Varblane, U. and Roolaht, T. (eds.), Innovation System in Small Catching-up Economics, New Perspectives on Practice and Policy, Heidelberg et al. : Springer, 2012.

[ 5 ] Cohendet, P., Grandadam, D. and Simon, L., "The Anatomy of the Creative City," Industry and Innovation, 17, 2010, pp. 91-111.

[ 6 ] Cooke, P. and Memedovic, O., Strategies for Regional Innovation Systems : Learning Transfer and Applications, Vienna : United Nations Industrial Development Organization (UNIDO), 2003.

[ 7 ] Cornes, R. and Hartley, R., Joint Production and Share Functions, Working Paper, Department of Economics, Keele University, 2001.

[ 8 ] Deutsches Institut für Wirtschaftsforschung (DIW), Die wirtschaftliche Bedeutung Adlershofs : Auswirkung auf Wertschöpfung, Beschäftigung und Steueraufkommen in Berlin, http://www.adlershof.de/uploads/tx_psdo kugalerie/DIW_Studie_adlershof.pdf, 2010.

[ 9 ] Dressen, M., Regionales Gewerbeflächenmanagement: Kooperation in der Gewerbeflächenpolitik als Strategie regionaler Wirtschaftsförderung, Dortmund : Institut für Landes- und Stadtentwicklungsforschung und Bauwesen des Landes Nordrhein-Westfalen, 2004.

[10] Erber, G., Public Infrastructure Productivity and Competitiveness, Analysis of Relative Differences and Impacts with Regard to U.S. and German Industries, Discussion Paper 115, Berlin : Deutsches Institut für Wirtschaftsforschung (DIW), 1995.

[11] European Commission, Working for the Regions, EU Regional Policy 2000-2006, Luxembourg : Office for 
Official Publication of the European Communities, 2004.

[12] European Commission, European Grouping of Territorial Cooperation, created by Regulation (EC) No 1082/2006 of the Council and the European Parliament of 5 July 2006, 2006.

[13] Florida, R., Cities and the Creative Class, Abingdon : Routledge, 2004.

[14] Fagerberg, J. and Srholec, M., The Role of "Capabilities" in Development: Why Some Countries Manage to Catch Up While Others Stay Poor, DIME Working Paper 2007.08, University of Oslo, 2007.

[15] Feng, X. and Friedrich, P., "Ansätze einer Theorie des Verkaufs von Treuhandvermögen an Kommunen," Jahrbuch für Sozialwissenschaft, 14, 1999, pp. 233-277.

[16] Fiedler, H. and Wodtke, K., Innovationszentren in Deutschland, Österreich und der Schweiz, Berlin : Weidler Verlag, 1991.

[17] Friedrich, P., "Modelle des kommunalen Industrieansiedlungswettbewerbs," Karlruher Beiträge zur Wirtschaftspolitik und Wirtschaftsordnung, 6, 1977, pp. 19-90.

[18] Friedrich, P. and Lindemann, S., "A Two-levelled Approach to Municipal Competition in Business Promotion," in : Bojar, E. (ed.), Competition and Coexistence in the Process of European Integration, Warsaw : Polish Scientific Publishers, 2000, pp. 99-126.

[19] Friedrich, P. and Nam, C.W., "Economic Decline and Public Intervention : Do Industrial Zones Matter," in : Capello, R. and Nijkamp, P. (eds.), Economic Decline and Public Intervention: Advances in Regional Economics, Northampton : Elsevier, 2009, pp. 495-523.

[20] Fritsch, M., “Co-operation in Regional Innovation Systems,” Regional Studies, 35, 2001, pp. 297-307.

[21] Glaeser, E.L., Kallal, H.D., Scheinkman, J.A. and Shleifer, A., “Growth in Cities,” Journal of Political Economy, 100, 1992, pp. 1126-1152.

[22] Grabow, B., Henckel, D. and Hollbach-Grömig, B., Weiche Standortfaktoren, Stuttgart : W. Kohlhammer, 1995.

[23] Gray, C., "Growth Orientation and the Small Firm," in : Caley, K., Chell, E., Chittendon, F. and Mason, C. (eds.), Small Enterprise Development, London : Sage Publications, 1992, pp. 59-71.

[24] Grossman, G. and Helpman, E., Innovation and Growth in the Global Economy, Cambridge MA : MIT Press, 1991.

[25] Hoekman, J., Frenken, K. and van Oort, F.G., "The Geography of Collaborative Knowledge Production in Europe," Annals of Regional Science, 43, 2009, pp. 721-738.

[26] Hotelling, H., "Stability in Competition," Economic Journal, 39, 1929, pp. 41-57.

[27] Kerstin, J., "Construction, City Planning and Zoning, Annual Report, Germany,” ius publicum network review, www.ius-publicum.com, 2011.

[28] Lambertini, L. and Mosca, M., Give to Ceasar What Is Ceasar's. Or Give to Launhardt What We Are Thinking Is Bertrand's, www2dse.unibo.it/lambertini/hoperev.pdf.

[29] Lancaster, K., “A New Approach to Consumer Theory,” Journal of Political Economy, 74, 1966, pp. 132-157.

[30] Landry, C., The Creative City : A Toolkit for Urban Innovators, London : Earthscan, 2012.

[31] Launhardt, W., Mathematische Begründung der Volkswirtschaftslehre, Leipzig: Teubner, 1885.

[32] Lehmann-Grube, U. and Pfähler, W., “Gewerbeflächenpolitik im Standortwettbewerb,” Wirtschaftsdienst, 1998/1, 1998, pp. 55-64.

[33] Lindemann, S., Theorie und Empirie des kommunalen Industrieansiedlungswettbewerbs, Baden-Baden : Nomos, 1999.

[34] McCann, E.J., "Inequality and Politics in the Creative City-Region : Questions of Livability and State Strategy,” International Journal of Urban and Regional Research, 31, 2007, pp. 188-196.

[35] Mills, E.S. and McDonald, J.F., Sources of Metropolitan Growth, New Brunswick NJ : Center for Urban Policy Research, Rutgers University, 1992.

[36] Ministerium für Stadtentwicklung, Wohnen und Verkehr des Landes Brandenburg (MSWV), Gewerbeflächenbedarf in Brandenburg : Eine Arbeitshilfe zur Flächenprognose, Potsdam, 2002.

[37] Nauwelaers, C. and Wintjes, R., SME Policy and the Regional Dimension of Innovation: Towards a New Paradigm for Innovation Policy?, MERIT-University of Maastricht, Maastricht (mimeo), 2000.

[38] Neumann, M., Theoretische Volkswirtschaftslehre III, Wachstum, Wettbewerb und Verteilung, Munich : Vahlen, 
1994.

[39] Newman, P. and Thornley, A., Urban Planning in Europe : International Competition, National Systems and Planning Projects, Abingdon : Routledge, 1996.

[40] Oates, W.E. and Schwab, R., "Economic Competition among Jurisdictions, Efficiency Enhancing or Distortion Inducing?,” Journal of Public Economics, 35, 1988, pp. 333-354.

[41] Ponzini, D. and Rossi, U., "Becoming a Creative City : The Entrepreneurial Mayor, Network Politics and the Promise of an Urban Renaissance,” Urban Studies, 47, 2010, pp. 1037-1057.

[42] Puttnam, R., Making Democracy Work : Civic Traditions in Modern Italy, Princeton : Princeton University Press, 1993.

[43] Rothwell, R., "The Role of Small Firms in Technological Innovation,” in : Curran, J., Stanworth, J. and Watkins, D. (eds.), The Survival of Small Firms, London : Ashgate, 1986, pp. 114-139.

[44] Schumpeter, J.A., The Theory of Economic Development, Cambridge, MA : Harvard University Press, 1934.

[45] Steinkühler, R.H., Technologiezentren und Erfolg von Unternehmensgründungen, Wiesbaden : DUV, 1994.

[46] Sternberg, R., Technologiepolitik und High-tech Regionen - ein internationaler Vergleich, Münster : LIT Verlag, 1995.

[47] Wolfe, D., "Social Capital and Cluster Development in Learning Regions," in : Holbrook, J.A. and Wolfe, D. (eds.), Knowledge, Clusters and Regional Innovation : Economic Development in Canada, Kingston : School of Policy Studies, Queen's University, 2002, pp. 11-38.

[48] Zwicker-Schwarm, D., Grabow, B., Schneider, S., Spath, C. and Wagner, A., Stadtentwicklungskonzept für Gewerbeflächen, Difu-Impulse 4, Berlin : Deutsches Institut für Urbanistik gGmbH, 2010. 